\title{
A Short Review of Influencing Factors of Islamic Architecture in Aleppo, Syria
}

\author{
Emad Noaime \\ Architectural Engineering \\ Department \\ College of Engineering \\ University of Hail \\ Saudi Arabia \\ e.noaime@uoh.edu.sa \\ Mabrouk Touahmia \\ Civil Engineering \\ Department \\ College of Engineering \\ University of Hail \\ Saudi Arabia \\ m.touahmia@uoh.edu.sa
}

\author{
Ahmed Osman \\ Architectural Engineering \\ Department \\ College of Engineering \\ University of Hail \\ Saudi Arabia \\ ah.ibrahim@uoh.edu.sa
}

\author{
Yahya Nasser \\ Architectural Engineering \\ Department \\ College of Engineering \\ University of Hail \\ Saudi Arabia \\ y.alfraidi@uoh.edu.sa
}

\author{
Mohamed Ahmed Said \\ Architectural Engineering \\ Department \\ College of Engineering \\ University of Hail \\ Saudi Arabia \\ masnmas2@yahoo.com
}

\author{
Khaled Salah \\ Architectural Engineering \\ Department \\ College of Engineering \\ University of Hail \\ Saudi Arabia \\ k.elkhayat@uoh.edu.sa
}

\author{
Ghazy Abdullah \\ Architectural Engineering \\ Department \\ College of Engineering \\ University of Hail \\ Saudi Arabia \\ g.albaqawy@uoh.edu.sa
Mohamed Hassan
Department
College of Engineering
University of Hail
Saudi Arabia \\ Architectural Engineering \\ mo.abdelhafez@uoh.edu.sa
}

\begin{abstract}
This research aims to examine Aleppo's distinctive architectural design profiles, most precisely those of residential buildings, and to highlight factors that indicate how the Islamic culture influenced the architectural structure in the pre-civil war era. Descriptive research, observation, and documentation of architectural elements that determine the general characteristics of housing in the city of Aleppo were used. The study focused on Wakil and Zamriah houses as case studies because of their accessibility and excellent exemplary style. The current study sheds light on the history of Aleppo's urban development and its influence by the Islamic civilization during the late Ottoman era up to the Syrian civil war in 2011. It is shown how Islamic civilization influenced Aleppo's residential buildings in terms of simplicity, respect for human scale, equality, and privacy.
\end{abstract}

Keywords-influence; Islamic architecture; Aleppo; residential buildings

\section{INTRODUCTION}

Architects not just design buildings but also shape the very definitions used in design, including the definition of space relationships and different design styles [1]. The main aim of architectural design is to create beautiful places that are environmentally appropriate with minimal negative impact [2]. A main concern is to achieve the best approach in evolving spatial and formal solutions [3]. Modern architecture however has paid little attention to the concept of privacy. This is initiated by the increasing needs of advanced industrial countries, with most Arab countries gradually following [4]. Traditional Islamic architecture has thus been gradually abandoned in residential areas and is now mostly used on the folklore of heritage [5]. Aleppo is a historic multi-cultural city with a complex mix of Syrians, Kurds, Iranians, Turkmen, and
Armenian [6]. In 2011, it was Syria's largest city with a population of 2.5 million people, a UNESCO World Heritage site that has been described as Syria's commercial capital. Aleppo is one of the oldest cities in the world, maintaining its continuity as an inhabited city for more than 5000 years. It is characterized by the plateau in its center, which dates back to the third or the fourth millennium BC [7].

Aleppo, known in the Roman, Hellenistic and the Byzantine era as Beroea, is characterized by the straight street, which extends from the western gate of the city (the gate of Antioch) to the east, at the bottom of the castle. This axis in the middle linked with the rectangular shaped Agora, which forms the site of the now Great Mosque. Aleppo and Damascus are characterized as Islamic cities built on Roman planning bases. The city is still changing according to the needs of its inhabitants, without losing however the elements of different civilizations, especially in the historic center of the city within its walls. The golden period of Aleppo was in the $12^{\text {th }}$ and $13^{\text {th }}$ centuries during the reign of the Zengids and the Ayyubids, when the city played an important role in the conflict between Islam and the Crusaders, and due to its geographical location it became a commercial link between the East and the West [8]. There are sites that still give a great example of stone architecture that lasted until the $18^{\text {th }}$ and $19^{\text {th }}$ centuries. Most of the buildings of the city of Aleppo today, with its old and modern parts, are built of stone. After the fall of the Ottoman Empire, Damascus began to overtake Aleppo's economic and political role in Syria $[8,9]$. However, old Aleppo remains relatively conservative in terms of architectural elements compared to other historical centers in the Islamic world. Along with Fez and Sana'a, Aleppo represents some of the 
most complete and important examples of traditional Islamic cities in the Islamic world. Today, Aleppo is the home of around two million people and is the second most populated city in Syria after Damascus, although the exact number fluctuates heavily due to the civil war [10]. Aleppo is also considered the economic center of the northern Syria. The ancient city lies inside and outside the walls, and its population reached 120,000 in an area of 350 acres [11], mostly living in two story traditional houses with inward courts.

\section{FACTORS AFFECTING THE ARCHITECTURAL PROFILE}

Islamic architecture is the result of the interaction between Muslims and the social directives originating from Islamic law. The surrounding Islamic environment with its climatic, spatial and cultural elements in its broad sense also weighs in. The general profile of Islamic architecture reflects these influences through organic and spontaneous architectural profiles that illustrate a simplicity and purity of architectural thought [1214]. These factors and their influence are further discussed in the following sections.

\section{A. Social Factors}

One of the most important things that characterize Islamic architecture in general and housing in particular, is its distinction in privacy, which is rather important within Arab traditions [15]. The house represents a large part of social life style formulated by the Islamic culture. This was further organized by the legislation of the Hijab which stipulates the separation of men from women and provides a detailed system for the distinction of family members and others [16-18]. The legislation is of two types: permission to enter the house from outside and permission within the same house to enter rooms.

\section{B. The Security-Political Factor}

As a result of the often acts of aggression and warfare from outsiders, as well as internal safety issues, buildings were clustered and formed facades extending on both sides of the streets [19]. This reflected the demand to minimize the number and size of entrances. The external facades were also modest and not that representative of the interior, leading to a great contradiction between the inside and outside of richer houses $[12,13]$. On the other hand, this created an obvious psychological need that led to excessive attention in the decoration and beauty of interior spaces [20].

\section{The Economic Factor}

The wealth of the residents have a direct effect on architecture design of houses, evident mostly in the multiple courtyards found in wealthier houses, each one often designated for a certain activity. There could be a courtyard for "Salamlek" (for men and guests), another courtyard for "Haremlek" (especially for women), and sometimes a third courtyard "Khadamlek" (for the servants, especially for guests served by servants as a sign of wealth and richness) [21]. The entrance of the house is generally the point at which its inhabitants and visitors move between the "Salamlek" and the "Haremlek". The entrance also connects the exterior and the interior and thus received a great attention in design. Most entrances offer indirect access with minimum or no visibility of the interior and the refraction, according to the living standards of the family, can be either simple or complex [12-14]. The houses are generally lacking openings or external windows that overlook the road. If such openings exist, they are placed on the top of the wall, often in the second floor and covered with "Mashrabiyas" or similar elements, to ensure the privacy of the residents. It is believed that the creation of "Mashrabiyas" [22] emerged for this purpose, and later on they were employed for ventilation and other purposes [23]. Examples can be found in Morocco [24], Saudi Arabia [25], and Kuwait [26].

\section{Environmental and Physical Factors}

\section{a) The Surrounding Environment}

The environment surrounding any urban setup has a clear impact on its formation. Architecture is usually influenced and in accordance with the surrounding environment [27]. The desert environment and its impact on the formation of Islamic architecture are vividly visible [27].

b) Local Building Materials and their Impact on the Formation of Islamic Architecture

The employment of raw building materials such as wood palm, stone, marble, gypsum, and treated mud is a common feature in Islamic architecture $[12,13,27,28]$. Local construction materials were largely used with building techniques creating vivid differences in architectural expression $[12,13,29]$.

\section{2) The Aesthetic Factor}

The urban environment is rich, interesting and in constant development [3]. The aesthetic factor is also considered, usually combined with other factors. An obvious example is the mashrabiyas which are designed in distinctive artistic styles. An additional factor is height restrictions usually present in Islamic architecture as a result of respect for other residents and also as a mean to suppress material competition between residents [30, 31]. Thus, an Islamic urban environment is characterized by uniformity that often makes the facades of different houses look as one facade abiding with technical and aesthetic rules.

\section{METHODOLOGY}

Descriptive research was used in carrying out this study as it describes the characteristics of the population or the phenomenon under study without influencing it in any way [32, 33]. This paper uses observation and documentation combined with literature review in order to further portray the general housing characteristics in the city of Aleppo. The Wakil and Zamriah houses are used as case studies because of their accessibility and their excellent exemplary style.

\section{CASE STUDIES}

\section{A. Wakil House}

Bayt Wakil [34] is situated in the Jdeide quarter on Sissi Street. It was built in the $18^{\text {th }}$ century, and is considered an ideal example of wealthier houses of that period. It is full of decorations and wooden claddings, including two attached houses that are best known for their intricate wooden paneling. Carved in 1603, the depictions show biblical scenes featuring Virgin Mary, Christ, and his disciples. The panels are now 
displayed in the Aleppian Hall in the Islamic section of the Pergamon Museum in Berlin, Germany. Wakil house has been renovated many times, adapting multiple functions throughout the previous century. It currently functions as a restaurant and a small inn [35]. Figures 1-3 are examples of its vault-like style while the supporting structure is decorated with arches with wooden pattern. Figure 4 shows the facade of the Northern part. The allocation of an important main room facing the north, overlooking the inner courtyard, considered a key element in the design, can be seen in [35].

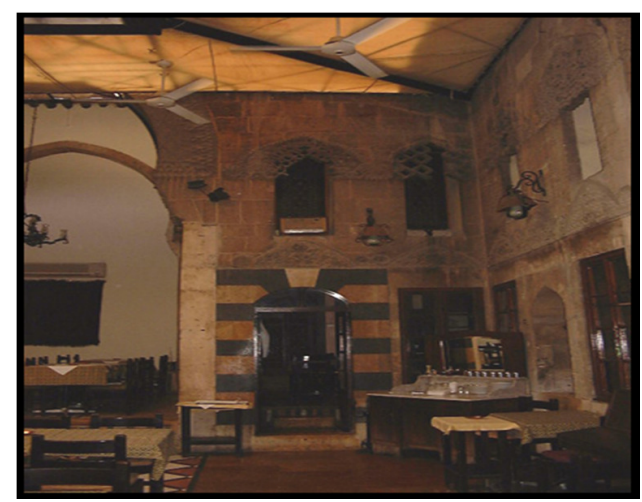

Fig. 1. Interior part

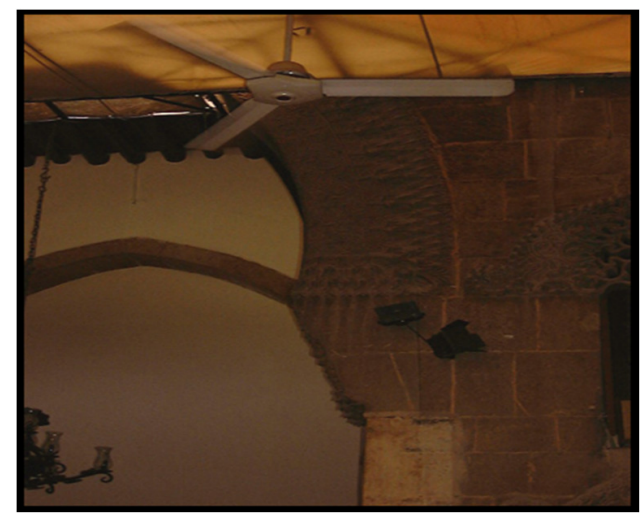

Fig. 2. A wooden column

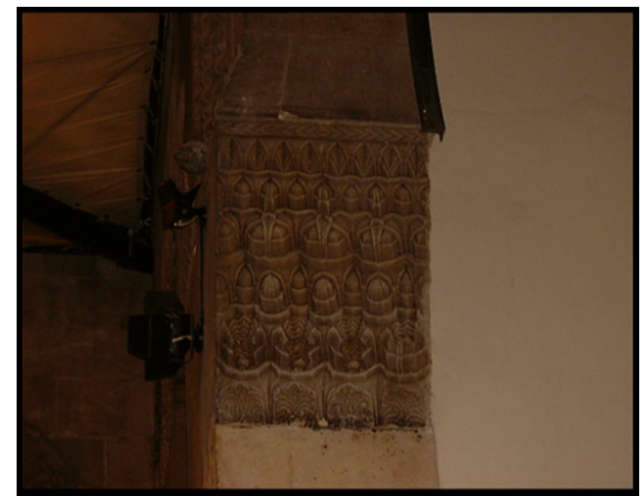

Fig. 3. Column detail after renovation

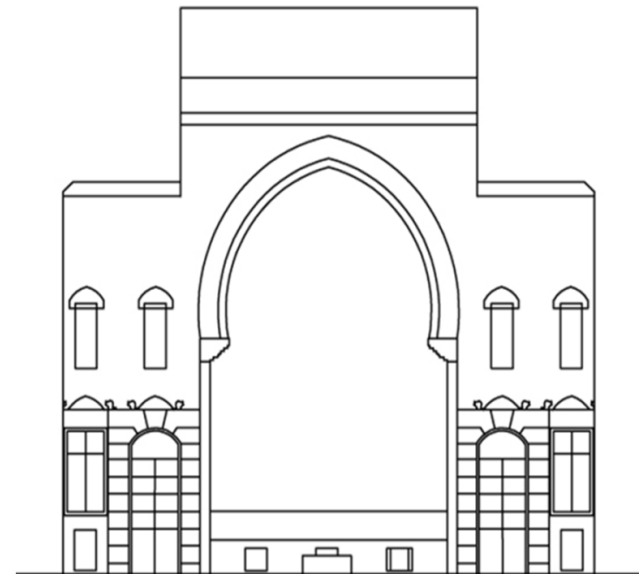

Fig. 4. North facade of Wakil house

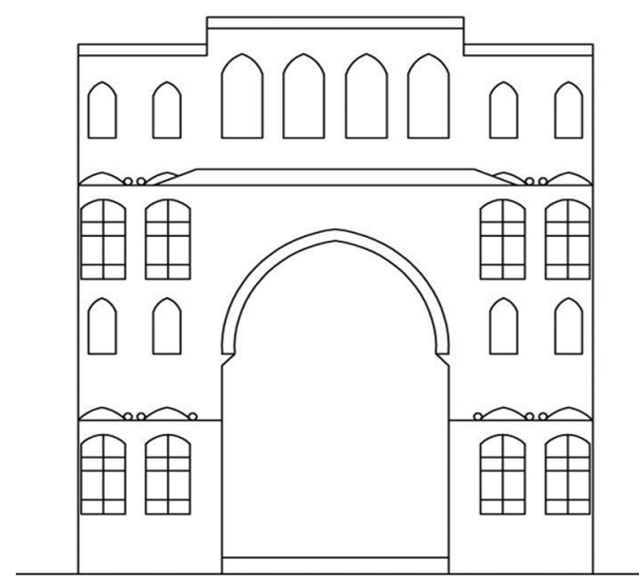

Fig. 5. South facade of Wakil house

The continuity of the simple rhythm at the horizontal and at the vertical level should be noted as well as the complex rhythm in the northern facade. The southern facade similarly shows balance and rhythm (Figure 5). Figures 6-8 are examples of the vault-like style adopted in this building showing details of the arches.

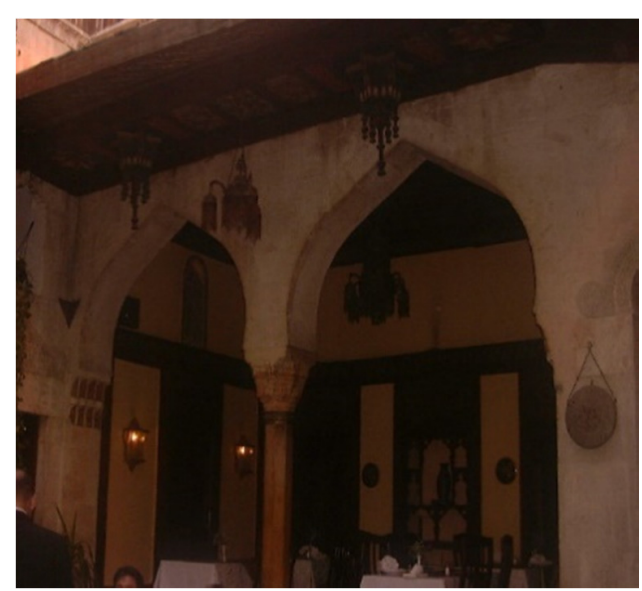

Fig. 6. Typical arch 


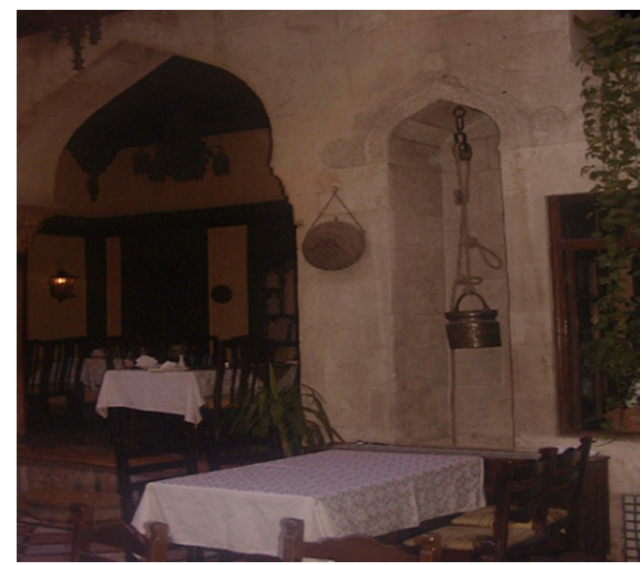

Fig. 7. Arch resting on a square column

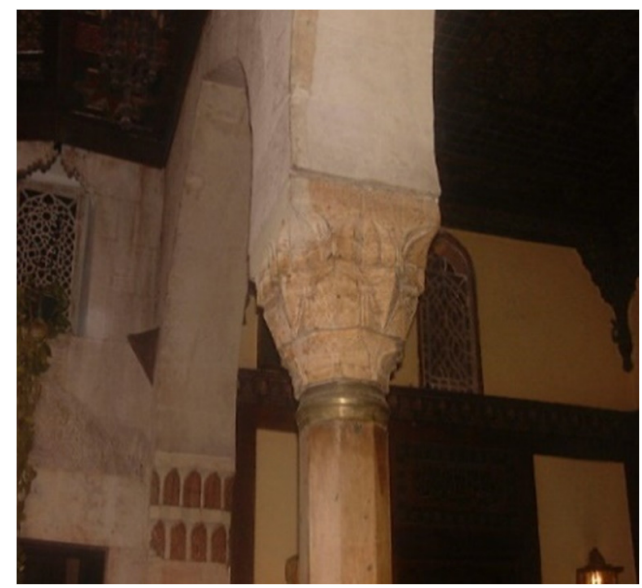

Fig. 8. Arch resting on a round column

\section{B. Zamriah House}

Zamriah or Zamaria [36] house was one of the finest boutique hotels in Aleppo, lovingly restored from a magnificent Ottoman home. An asymmetrical pattern can be seen in west and east sides. Similarly to the Wakil house, a simple rhythm can be observed at the horizontal and at the vertical levels. Views and drawings of the house are shown in Figures 9-13.

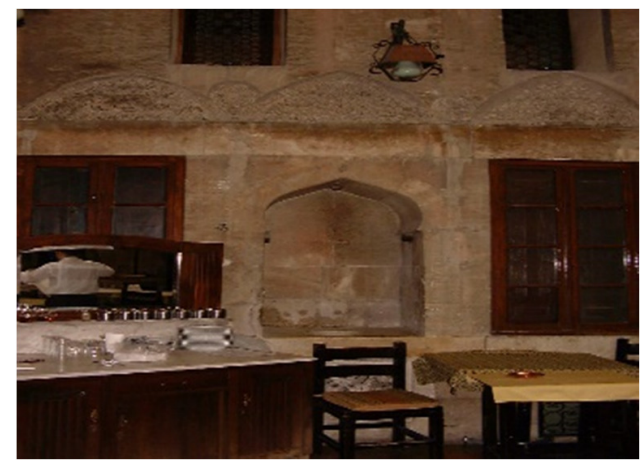

Fig. 9. Interior part - Zamriah house (a)

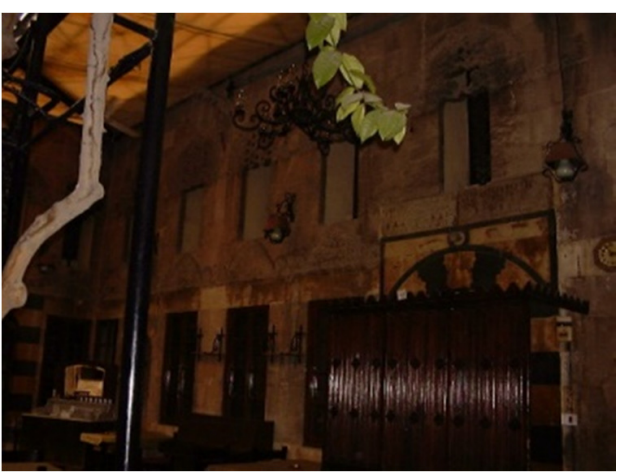

(b)

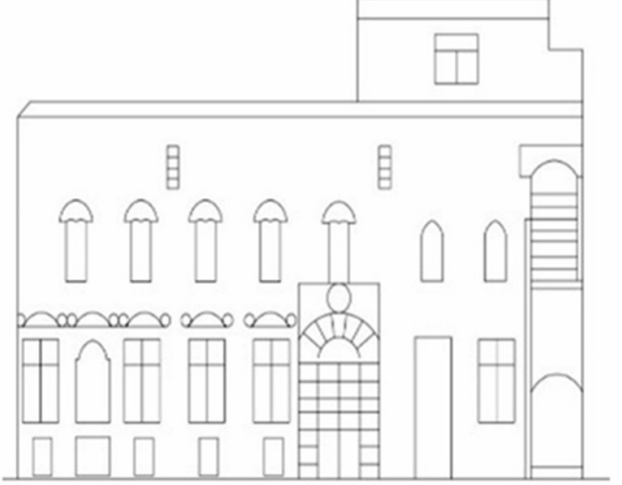

Fig. 10. East facade - Zamriah house

(a)

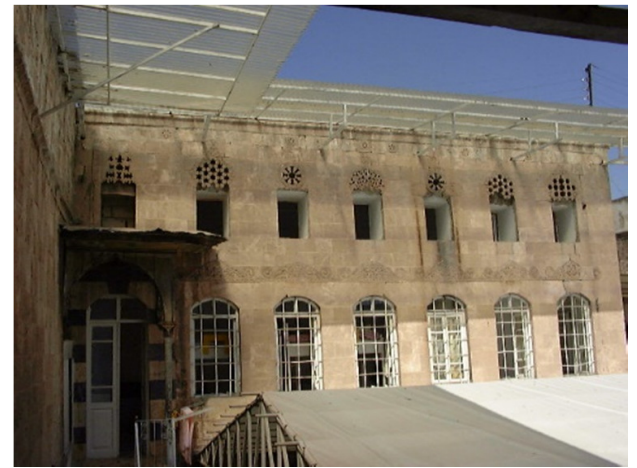

(b)

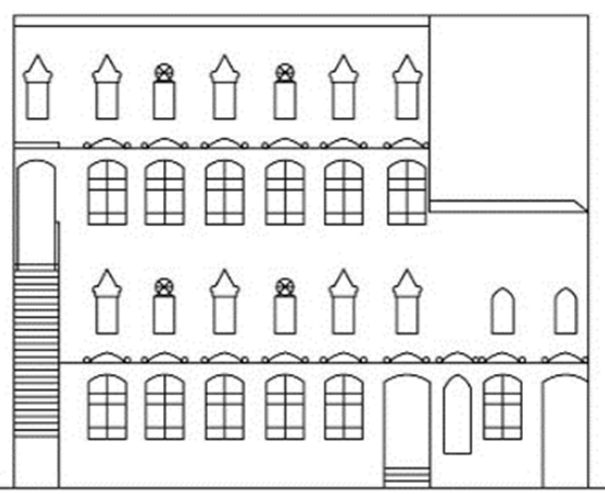

Fig. 11. West facade - Zamriah house

\section{CONCLUSION}

The doctrine and philosophy of Islam has a special effect in Islamic architecture, not only in terms of increased privacy and 
social separation but also in terms of mutual respect between neighbors and suppression of exhibitionism. This paper offers a short review on the factors that have influenced Islamic architecture in Aleppo, Syria. Two case studies are briefly discussed as examples. Some common characteristics are the presence of a main room which faces north and overlooks the inner courtyard, the small size and elevated position of outward facing openings in contrast with the inner facing ones, the use of decorations in the interior facades, the plainer design of exterior facades, the simplicity in form, and the respect of human scale.

\section{ACKNOWLEDGMENT}

The authors would like to acknowledge the Architectural Engineering Department, College of Engineering, University of Hail, Saudi Arabia for their support.

\section{REFERENCES}

[1] D. E. Hepler, P. R. Wallach, D. Hepler, Drafting and design for architecture \& Construction, Cengage Learning 2012

[2] J. Hill, Actions of architecture: Architects and creative users, Psychology Press, 2003

[3] S. Odin, Tragic beauty in Whitehead and Japanese aesthetics, Lexington Books, 2016

[4] T. A. Soomro, M. A. Soomro, A. N. Laghari, D. K. Bhangwar, M. A. Soomro, "Fading legacy of the architectural heritage of the historic core of Karachi”, Engineering, Technology \& Applied Science Research, Vol. 8, No. 2, pp. 2735-2740, 2018

[5] J. A. Akbar, Earth development in Islam Al Resala, 1998

[6] D. Darke, The merchant of Syria: A history of survival, Oxford University Press, 2018

[7] Bureau Ali Saad Architecture Urbanism, “Aleppo city vision”, available at: https://www.bureaualisaad.eu/Aleppo-City-Vision

[8] R. Burns, Aleppo: a history, Routledge, 2017

[9] R. Burns, Damascus: a history, Routledge, 2007

[10] Syria Population, 2020, available at: https:/worldpopulationreview.com/ countries/syria-population/

[11] Alepposeife, “Aleppo history", available at: http://www.historischealeppo-seife.de/engl_history.html

[12] A. Petruccioli, K. K. Pirani, Understanding islamic architecture, RoutledgeCurzon, 2002

[13] M. Bilal Bagbanci, "Reinforcement and Restoration Studies of the Edremit Ataturk House", Engineering, Technology \& Applied Science Research, Vol. 10, No. 2, pp. 5346-5351, 2020

[14] R. Hillenbrand, Islamic architecture: Form, function, and meaning, Columbia University Press, 2004

[15] Z. Othman, R. Aird, L. Buys, "Privacy, modesty, hospitality, and the design of Muslim homes: A literature review", Frontiers of Architectural Research, Vol. 4, No. 1, pp. 12-23, 2015

[16] R. H. Putri, "Implementation of hijab concept in Arab house Pasar Kliwon Surakarta", Journal of Islamic Architecture, Vol. 2, No. 3, pp. 106-113, 2013

[17] S. N. Nahid, Accomodating the Muslim Women Privacy (hijab) Requirement with Ventilation Needs in Malaysian Terrace Houses, MSc Thesis, University Putra Malaysia, 2001

[18] M. S. Musa, N. bin Misnat, A. bin Talib, M. D. bin Mohamad, N. Ahmad, "Islamic design guidelines: an analysis of the aspect of hijab in the main entrance design of Kutai Malay house", 2nd International Conference on Innovation and Technology for Sustainable Built Environment 2014, Ipoh, Malaysia, May 27-28, 2014

[19] S. Omer, "Towards understanding Islamic architecture", Islamic Studies, Vol. 47. No. 4, pp. 483-510, 2008
[20] H. U. Khan, "Architect-designed houses: From traditional to modern, a changing paradigm in the Islamic world", International Journal of Islamic Architecture, Vol. 8, No. 1, pp. 5-29, 2019

[21] E. M. Z. Al Abidin, "The courtyard houses of Syria", in: Courtyard Housing: Past, Present and Future, Taylor \& Francis, 2006

[22] A. F. Ashour, "Islamic architectural heritage: Mashrabiya", WIT Transactions on The Built Environment, Vol. 177, pp. 245-253, 2018

[23] R. Abdelkader, J. H. Park, "The evolving transformation of mashrabiya as a traditional Middle Eastern architecture element", International Journal of Civil \& Environmental Engineering, Vol. 17, No. 1, pp. 1520, 2017

[24] C. Walker, "6 of the world's most extraordinary sleepovers", available at: https://collectivehub.com/2017/03/6-of-the-worlds-most-extraordina ry-sleepovers

[25] K. Wells, "Indoor courtyards", available at: https://www.pinterest. com/katewells33/indoor-courtyards/

[26] Skyscrapercity, "Arab organizations headquarters", available at: http://www.skyscrapercity.com/showthread.php?t=655254

[27] H. Fathi, Architecture and the environment, Al Maarif Foundation for Printing and Publishing, 1977

[28] E. Lambourn, "Brick, timber, and stone: Building materials and the construction of Islamic architectural history in Gujarat", Muqarnas, Vol. 23, pp. 191-217, 2006

[29] A. AliYassin, N. Utaberta, "Architecture in the Islamic civilization: Muslim building or Islamic architecture", Journal of Islamic Architecture, Vol. 2, No. 2, pp. 52-60, 2012

[30] T. Okasha, Aesthetic values in Islamic architecture, Dar El Shorouk, 1994

[31] M. Ben Hamouche, "Sight Restrictions in Maghrib Muslim Architecture", Intellectual Discourse, Vol 7, No 2, pp. 133-15, 1999

[32] N. L. Leech, K. C. Barrett, G. A. Morgan, SPSS for intermediate statistics: Use and interpretation, Lawrence Erlbaum Associates, 2005

[33] V. A. Lambert, C. E. Lambert, "Qualitative descriptive research: An acceptable design", Pacific Rim International Journal of Nursing Research, Vol. 16, No. 4, pp. 255-256, 2012

[34] Archnet, "Courtyard houses of Aleppo", available at: https://archnet.org/collections/1210/sites/2860

[35] A. Hadjar, Historical monuments of Aleppo, Automobile and Touring Club of Syria, 200

[36] Syr-Res, "The Arab house in Aleppo: The house of Wakil, one of the most famous Arab houses in Aleppo", available at: http://www.syrres.com/article/13403.html (in Arabic) 